\title{
CONSTITUENT POWER AND THE LIMITS OF ADJUDICATION: KOSOVO AND QUEBEC
}

\author{
Matthew Kennedy ${ }^{*}$
}

\begin{abstract}
Law, and therefore courts, can only make sense of collective agency in terms of constituted power that is power exercised in conformity with law. However, constituent power, insofar as it purports to create a new legal order, cannot act in conformity with the existing legal order. Constituent power can only be understood as lawful, therefore, if it is understood retroactively, from the perspective of the new legal order. This article considers the ICJ's treatment of the constituent power of 'the People' in the Kosovan declaration of independence, and the Supreme Court of Canada's consideration of the Quebecois legal right to secede. Considering the literature on constituent power and the ontology of 'the People', this article suggests that democracy and the rule of law offer a partial solution to the paradox of constituent power. It introduces John Searle's ontology of 'institutional facts', arguing that the nature of the constituent entity can be understood as a 'status function' created by a 'Declaration'. It concludes by considering the limits to the justiciability of constituent power and the corollary necessity for recognition, or what Derrida calls a 'last instance'.
\end{abstract}

\section{Keywords}

Constituent Power, Political Community, Speech Act Theory, Law and Politics

\section{Introduction: the paradox of constituent power}

In both the Accordance with International Law of Unilateral Declaration in respect of Kosovo, Advisory Opinion ('the Kosovo Opinion') ${ }^{1}$ and the Reference re Secession of Quebec ('the Quebec Secession Case') ${ }^{2}$ the 'will of the people' was recognised as a source of constituent power. However, in both cases the relevant court acknowledged that 'the people' could only express its will in a legally cognizable way through representatives; that is, through constituted power. This presents something of a paradox: constituent power was only judicially intelligible as constituted power. In the Kosovo Opinion the International Court of Justice ('ICJ')

\footnotetext{
LLM, University of Cambridge.

1 Accordance with International Law of the Unilateral Declaration of Independence in Respect of Kosovo, Advisory Opinion, Advisory Proceedings, ICJ Reports 2010, 403.

2 Reference re Secession of Quebec [1998] 2 SCR 217.
}

Copyright $\odot$ the Author(s).

This work is licensed under a Creative Commons Attribution-NonCommercial-NoDerivs 3.0 License. 
acknowledged that the authors of the declaration of independence were 'persons who acted together in their capacity as representatives of the people of Kosovo', that is as constituted power, yet also held that they acted 'outside the framework of the interim administration, ${ }^{3}$ that is as constituent power constituting a new legal order. In the Quebec Secession Case, the Supreme Court of Canada accepted that a clear expression by a clear majority of the Quebecois in favour of secession would legitimate attempts by their representatives to negotiate an exit from the Canadian federation. The Court however, rejected the simple majoritarian understanding of popular sovereignty which was advanced by the amicus curiae. The will of the Quebecois people must, the Court held, be mediated through the Canadian Constitution; the constituent power of the Quebecois could only be effective as such by operating within the existing legal order, that is, as constituted power.

This article explores the paradox of constituent power. Law, and therefore courts, can only make sense of collective agency in terms of constituted power; that is, power exercised in conformity with law. However, constituent power, insofar as it purports to create a new legal order, cannot act in conformity with the existing legal order. Constituent power can only be understood as lawful, therefore, if it is understood retroactively, from the perspective of the new legal order. I will first consider the ICJ's identification of the authors of the Kosovan declaration of independence, and the criticisms which have been made of its findings. I will argue that these criticisms lack an adequate ontology of 'the people', and therefore fail to understand the declarators' claims to representative standing. I will then turn to the relationship between constituent power and existing legal orders. I will consider the status of the legal regime established under SC Res 1244 (10 June 1999) and UNMIK Reg 1999/1 (25 July 1999), and its bearing on the authors of the Kosovan declaration of independence. Lastly, I will consider the problem of 'retroactive' authorisation. I will consider the Supreme Court of Canada's argument in the Quebec Secession Case that de facto succession and international recognition cannot retroactively create a legal right to secede. I will also consider the way in which democracy and the rule of law offer a partial solution to the paradox of constituent power. I will conclude by considering the limits to the justiciability of constituent power and the corollary necessity for recognition, or what Derrida calls a 'last instance'.

\footnotetext{
Kosovo Opinion, para 109.
} 


\section{2 'Who is the signer of such acts?'}

Jure Vidmar has argued that the ICJ's 'pronouncement on the identity of the authors of the declaration may well be problematic from the aspect of the support of the will of the people for the alteration of the legal status of the territory' ${ }^{4} \mathrm{He}$ argues that 'a unilateral declaration of independence [...] cannot be issued by just anyone' but only those 'entitled to speak on behalf of the people' and who have 'the capacity to speak and act on behalf of the people.' This capacity is 'linked to' and derives not only 'from the will of the people' but also from 'effectiveness presumed under the Montevideo criteria for statehood'. 'The Kosovo Opinion', argues Vidmar, 'seems to confirm that." However, Vidmar finds a tension between the Court's finding that the authors of Kosovo's declaration of independence 'acted together in their capacity as representatives of the people of Kosovo' and its finding that they acted 'outside the framework of the interim administration.' The Court, Vidmar argues, 'ignored the crucial question, namely from where this capacity to act as representatives of the people of Kosovo' derives.' 8 For Vidmar this capacity

[...] derives from the institutions of self-government. The authors of the declaration occupy posts within these institutions and were elected to their posts according to the prescribed procedures. The institutions they represent, and not their personal integrity, give them the capacity to act [...] The Court's finding that the authors of the declaration had the capacity to act on behalf of the people of Kosovo is thus inherently linked to the institutions of self-government and it is not possible to separate the capacity to act from the institutions that give the individuals this capacity. But this is exactly what the Court did. It established that the individuals had the capacity to act and, in doing so, it silently derived this capacity from the institutions of self-government. But, in the next

4 J Vidmar, 'The Kosovo Advisory Opinion Scrutinized' (2011) 24 Leiden J of Int L 355, 357.

5 Ibid, 360.

6 Ibid, 360-361; Ioannidis, below n 47, 3, rightfully points out that '[w]hat the Court examined was the existence of rules regulating the act of communicating the intention to become an independent state' (emphasis original). If this is the case, the 'effectiveness' of the author may not be relevant to the legality of the declaration.

7 Vidmar, above n 4, 361.

8 Ibid. 
step the Court separated the representatives from their institutions and treated them as individuals. ${ }^{9}$

This reasoning, Vidmar argues, 'makes the declaration of independence formally questionable from the perspective of the will of the people. ${ }^{10}$ It is not altogether clear why this is the case. Vidmar himself admits that 'there is little doubt that independence is the wish of the majority of Kosovo's population' ${ }^{11}$ and that, as the ICJ held in the Western Sahara Advisory Opinion, ${ }^{12}$ 'there might exist circumstances in which the will of the people is obvious and public consultation is not necessary. ${ }^{13}$ In any event, Kosovo was not such a case. Indeed, as early as 1991, an underground referendum in Kosovo, in which 87 per cent of the electorate participated, returned a result of 99.87 per cent in favour of independence. ${ }^{14}$ Vidmar's argument that the declaration is questionable from the perspective of the will of the people seeks to rely on that which he elsewhere denies: that the authors could act other than in their capacity as members of the Assembly. It is, of course, open to Vidmar to criticise the ICJ's finding that the authors did not act in that capacity, but if he is understood as suggesting that they were, in fact, acting in that capacity, it would not seem open to him to suggest that the declaration of independence was not representative of the will of the people. Vidmar's argument may be that if the ICJ is correct then the declaration of independence is questionable from the perspective of the will of the people. I will show that this is not correct.

Vidmar is not, however, alone in this analysis of the ICJ's Opinion. Marcelo Kohen and Katherine Del Mar argue that:

[...] the very evidence that demonstrated the ultra vires nature of the UDI - that it was intended to operate outside the legal framework established by the UNSC - led the Court to reach the reverse conclusion that one would have expected. Instead of declaring the act to have been exercised ultra vires, the Court considered that the act was so far outside the realm of the competences of the PISG that

\footnotetext{
${ }^{9}$ Ibid (emphasis added).

${ }^{10} \mathrm{Ibid}, 362$.

${ }^{11}$ Ibid.

${ }^{12}$ Western Sahara Advisory Opinion, Advisory Proceedings, ICJ Reports 1975, 12.

${ }^{13} \mathrm{~J}$ Vidmar, 'International Legal Responses to Kosovo Independence' (2009) 24 Vanderbilt J of Trans L 779, 826.

${ }^{14}$ Ibid, 789 .
} 
it was not governed by the legal framework established by UNSCR 1244 to apply to the PISG. ${ }^{15}$

\section{According to Kohen and Del Mar:}

[a]11 the individuals who issued the UDI were acting in that capacity [as constituted organs of the PISG], since they considered themselves to be the 'democratically elected representatives'. As a matter of course, they were elected within the framework of UNSCR 1244 and as organs constituting the PISG. ${ }^{16}$

Kohen and Del Mar do, appreciate the nature of constituent power. '[I]t is to be expected', they say:

[...]in those cases in which the relevant domestic legal system does not recognize a right to separate from the state in question that persons issuing a UDI would claim that the act is not governed by the applicable legal regime because they are performing a revolutionary act of a pouvoir constituant..$^{17}$

They go on to say that "[s]uch a claim is nothing more than the unilateral perception of those issuing a UDI'. ${ }^{18}$ This fails, however, to grasp the structure which such speech acts take.

Acts such as this belong to what John Searle calls Declarations, a 'fascinating class of speech acts', which combine the 'word-to-world and the world-to-word direction of fit'. That is to say, Declarations simultaneously represent how things are in the world and attempt to change the world to match the content of the speech act. Searle continues:

[They] have both directions of fit simultaneously in a single speech act. These are cases where we change reality to match the propositional content of the speech act and thus achieve world-to-word direction of fit. But, and this is the amazing part, we succeed in doing so because we represent the reality as being so changed. ${ }^{19}$

\footnotetext{
${ }^{15}$ M Kohen \& K Del Mar, 'The Kosovo Advisory Opinion and UNSCR 1244 (1999): A Declaration of “Independence from International Law”?' (2011) 24 Leiden J of Int L 109, 118.

${ }^{16}$ Ibid, 120-1.

17 Ibid, 118.

18 Ibid, 119.

${ }^{19}$ J Searle, Making the Social World: The Structure of Human Civilisation (2010) 12.
} 
To say that the claim to act as pouvoir constituant is 'nothing more than the unilateral perception of those issuing a UDI' neglects the fact that the 'truth' of such a claim can only be achieved by representing it as already being true. That is to say, in order to act as povoiur constituant, as representatives of the people, the authors of the UDI must represent reality and themselves as already being so changed. Far from representing the 'unilateral perception' of the authors, the success of such declarations is determined by the recognition of the claim by other members of the community, something which will be discussed further below.

Both Vidmar and Kohen and Del Mar assume that the authors of the declaration either had status which derived from the interim legal order established by the United Nations or they had no status whatsoever. Vidmar, for example, repeatedly argues that the ICJ found the authors of the declaration to be acting in their personal capacity', that it treated them as 'individuals', 'a group of individuals' or as 'individuals' with 'capacity to act'. Unfortunately, Vidmar's argument is not supported by the text of the ICJ's opinion. The Court referred to the authors as 'persons who acted together in their capacity as representatives. ${ }^{20}$ It is clear from this that the Court considered the authors' actions to be the actions of a collective entity, not simply the actions of manifold individuals. This collective entity was constituted, in the Court's opinion, by the authors' status as representatives of the people of Kosovo. There is similarly little textual support for Vidmar's contention that the Court 'silently derived this capacity from the institutions of self-government'. This rests on a tacit assumption, shared by both Vidmar and Kohen and Del Mar, that the authors of the declaration could only derive their capacity as representatives of the people of Kosovo from a pre-existing legal norm, in this instance from SC Res 1244 and UNMIK Reg 1999/1.

This assumption, that the capacity to represent must rest on a prior legal norm, is misguided. Such a position inevitably leads to an infinite regress of attribution and authorisation. ${ }^{21}$ Moreover, both Vidmar and Kohen and Del Mar collapse 'constituent into constituted power and politics into law, thereby hypostatizing the legal order into a self-grounding, self-serving and

\footnotetext{
${ }^{20}$ Kosovo Opinion, para 109.

${ }^{21}$ Kelsen recognised this: 'attribution has a regressive structure [...] [C]rucially, this regression is not infinite: relations of empowerment lead back to a "first constitution", enacted by an assembly or an individual. But whoever enacts the first constitution cannot be empowered to do so by a norm of positive law' (H Lindahl, 'Constituent Power and Reflexive Identity: Towards an Ontology of Collective Selfhood', in M Loughlin \& N Walker (eds), The Paradox of Constitutionalism: Constituent Power and Constitutional Form (2007) 9, 11).
} 
self-sustaining system of rules. ${ }^{22}$ This is, however, inevitable: the law 'can only make sense of collective agency in terms of constituted power, power exercised in conformity with the law. ${ }^{23}$ That is to say, constituent power (the will of the people) must be understood as being represented power exercised by agents or representatives. However, Vidmar and Kohen and Del Mar are wrong to assume that the authors' 'capacity to act on behalf of the people of Kosovo is thus inherently linked to the institutions of self-government ${ }^{24}$ established under the international legal order.

Hans Lindahl argues that 'constituent power only appears from the firstperson plural perspective. Collective self-government entails that the creation of norms involves a "We" as a unity in action." 25 However, 'whether or not a collective subject [i.e. a "We"] exists politically can only be established retrospectively, from within the unity of a legal order: political unity does not admit of pre-legal existential judgment. ${ }^{, 26}$ Jacques Derrida expresses a similar point in his assertion that " $t$ ]he "we" of the declaration speaks "in the name of the people." But this people does not exist. They do not exist as an entity, it does not exist, before this declaration, not as such. ${ }^{27}$ There is, therefore, 'a remarkable equivocity that goes to the heart of collective self-constitution':

On the one hand, there is no first-person plural perspective in the absence of an act that effects a closure by seizing the political initiative to say what goal or interest joins together the multitude into a people, and who belongs to the people [...] [The] invocation [of 'We'] fails not merely because there is no subject to whom the speech-act can be attributed, but because the author to whom the act would be attributed is authored by his attribution: 'there can be no "people" prior to the imputation of a will to them. ${ }^{28}$

That is to say:

\footnotetext{
${ }^{22}$ Ibid, 9.

${ }^{23}$ Ibid, 11 .

${ }^{24}$ Vidmar, above n 4, 361.

${ }^{25}$ Lindahl, above n 21, 10 (emphasis original).

${ }^{26}$ Ibid, 20. Likewise, 'no sense can be made of the unity of a legal order without the political unity implied in the first-person plural perspective of a "We" as a subject in constituent action': Ibid, 16.

27 J Derrida, 'Declarations of Independence', (1986) 7 New Political Science 7, 10 (emphasis original).

${ }^{28}$ Lindahl, above n 21, 18 (emphasis original).
} 
[W] hoever exercises constituent power must claim to act in the name of the collective, that is, must claim to act as a constituted power: he not only speaks about but also on behalf of 'our movement .... [...] An act can only originate a community by representing its origin. This paradox governs the attribution of legislation to a collective, for assigning the acts of individuals to a collective involves following a regressive strategy that takes us from the present to the past. But the 'end point' of attribution is not the initiating act of a collective subject existing in an original present; instead. Attribution leads back to 'a past which has never been a present. ${ }^{29}$

The critics of the ICJ fail to recognise that attribution leads back to a past which has never been a present and that, therefore, the 'representativity' of those who claim to act on behalf of the constituent power, those who claim to act as constituted power, is 'fully legitimated only by the signature, thus after the fact of the coup', in what Derrida terms a 'sort of fabulous retroactivity. ${ }^{30}$ This retroactive legitimation is generated, according to Lindahl, by 'the people' 'exercising their constitutional rights'. In doing so, 'they retroactively take up the first-person plural perspective of a "We" that has (already) enacted a constitution in its own interest. ${ }^{31}$ Moreover, although:

[...] no collective self exists independently of the individuals that compose it because [...] acts of self-attribution are in each case individual acts [...] the self to which they attribute these acts is a political unity, a 'We', the existence of which is not simply the summation of the manifold of individual acts of attribution. ${ }^{32}$

In the same way, the initial act of 'representivity' cannot, I argue, be reduced to the 'summation of the manifold of individual acts' insofar as the act purports to be an act by and of the incorporated political community, the 'We'. The acts 'of the people' are indissolubly linked to acts 'in the name of the people' 'because a people can never be directly present to itself as a subject in constituent action, an act can only be identified as its act by raising a representational or attributive

\footnotetext{
${ }^{29}$ Ibid, 18-9 (emphasis original).

${ }^{30}$ Derrida, above n 27, 10.

${ }^{31}$ Lindahl, above n 21, 19-20.

${ }^{32}$ Ibid, 20.
} 
claim. ${ }^{33}$ The 'capacity' of the authors to act as the representatives of the people of Kosovo could only therefore be retroactively authorised by the people exercising the constitutional rights conferred on them by the new constitution of Kosovo, not by SC Res 1244 or UNMIK Reg 1999/1.

I have argued that there is little textual support in the ICJ's opinion for the position taken by Vidmar and Kohen and Del Mar. However, there is support for their argument that the capacity of the authors of the declaration was derived from the international legal regime in the text of the declaration itself. In the text, the authors refer to themselves as 'the democratically-elected leaders of our people. ${ }^{34}$ Elections to the Assembly of Kosovo had been held on 17 November $2007^{35}$ and the declaration was signed by 109 of the 120 members of the Assembly returned in that election, in addition to the President of Kosovo (who was not a member of the Assembly). ${ }^{36}$ It is clearly this election to which the authors refer in the text of the declaration. I would argue, however, that this was a rhetorical strategy on the part of the authors who were conscious that 'whoever exercises constituent power must claim to act in the name of the collective, that is, must claim to act as a constituted power. ${ }^{37}$ It is clear from the text that they claimed to act in the name of a collective ('our people') whose 'will' the declaration 'reflects'. It is also clear that they purported to exercise constituent power in declaring 'Kosovo to be an independent and sovereign state' and 'a democratic, secular, multi-ethnic republic'. ${ }^{38}$ The authors claimed to act as a constituted power whose authority lay in the elections of the year before because the real "end point" of attribution is not the initiating act of a collective subject existing in an original present; instead attribution leads back to "a past which has never been a present". 39 The authors could only be empowered to act in this representative capacity at a point yet to come. Yet, as Derrida tells us, 'this future perfect, the proper tense for this coup of right [...] should not be declared, mentioned, taken into account. It's as though it didn't exist. ${ }^{\prime 4}$ The authors of the declaration could not appeal to the future in which their claim to exercise constituent power in the

\footnotetext{
${ }^{33}$ Ibid, 24. Derrida expresses this idea when he says "ii]t is still "in the name of" that the "good people" of America call themselves and declare themselves independent, at the instant in which they invent (for) themselves a signing identity': Derrida, above n 27, 11 (emphasis original).

${ }^{34}$ Text of the declaration of independence of 17 February 2008, cited in Kosovo Opinion, para 75.

${ }^{35}$ Kosovo Opinion, para 73.

${ }^{36}$ Ibid, para 76.

${ }^{37}$ Lindahl, above n 21, 19.

${ }^{38}$ Text of the declaration of independence of 17 February 2008, cited in Kosovo Opinion, para 75.

${ }^{39}$ Ibid.

${ }^{40}$ Derrida, above n 27, 10.
} 
name of the people of Kosovo had been retroactively legitimated and therefore had to appeal to a constative past event. ${ }^{41}$

In response to the question ' $[\mathrm{w}]$ ho is the actual signer of such acts', Derrida argues that 'the "representatives" themselves, they don't sign [...] In principle at least, because the right is divided here. In fact, they sign; by right, they sign for themselves but also "for" others.' He continues, ' $t$ ] hey speak, "declare”, declare themselves and sign "in the name of...": "[...] in the name and by the authority of the good people [...]"' 'It is, rather, 'the "good people" who declare themselves free and independent. ${ }^{42}$

Vidmar and Kohen and Del Mar neglect to develop an account of the ontology of 'the people' and, therefore, fail to define the status of the authors of the declaration as representatives of the people. Once the ontological nature of 'the people' and its relationship to the declaration's authors in constituting this people are properly understood, it becomes clear that it is not simply a question of whether or not the authors acted as one of the 'Institutions of Self-Government'. As Derrida says, the 'undecidability' between a performative structure (i.e. the authors as constituent power) and a constative structure (i.e. the authors as constituted power) 'is required in order to produce the sought-after effect'; ${ }^{43}$ that is, independence. The ICJ's reasoning ceases to be problematic from the perspective of the will of the people (formally or otherwise) once we acknowledge that the will of the people consists not in pre-authorisation but in individual acts of retroactive self-attribution.

According to Searle, all of institutional reality is created by speech acts that have the same logical form as Declarations. ${ }^{44}$ 'The People' is an institutional fact created by declarations of the same logical form and, like any other institutional fact, a 'people' only exists to the extent that a number of individuals are represented as existing as a group and to the extent that this representation is recognised or accepted by them. It is my argument that this ontology, grounded in a theory of speech acts, is best able to capture the paradox of constituent power.

\footnotetext{
${ }^{41}$ On the distinction between constative and performative in declarations of independence, see B Honig, 'Declarations of Independence: Arendt and Derrida on the Problem of Founding a Republic' (1991) 85 Am Pol Sci Rev 97. Honig argues (at 107) that Arendt similarly finds refuge in the fable of the past event of the American Declaration of Independence in order to anchor her conception of authority in modern politics. See above for discussion of the of the constative and performative elements of the Kosovan declaration of independence and below for discussion of what Derrida terms the 'last instance'. See also Honig's analysis at 105.

${ }^{42}$ Derrida, above n 27, 9.

${ }^{43}$ Ibid (emphasis original).

${ }^{44} \mathrm{~J}$ Searle, above n 19, chapter 5.
} 
It does this because declarations and the paradox share the same logical structure. Just as declarations succeed in achieving world-to-word fit by representing reality as being so changed, so too constituent power succeeds by representing itself as constituted power, i.e. by representing the reality it constitutes as having already been constituted.

\section{3 'A measure the significance and effect of which would lie outside the order'}

The ICJ, in the Kosovo opinion, held that 'the declaration of independence, therefore, was not intended by those who adopted it to take effect within the legal order created for the interim phase' and, more importantly, 'nor was it capable of doing so.' It was 'a measure the significance and effects of which would lie outside that order. ${ }^{\text {,5 }}$ Indeed, Marc Weller has argued that a 'declaration of independence steps outside the previously existing domestic legal context and cannot be evaluated according to that domestic law. ${ }^{46}$ Or, as Michael Ioannidis puts the point, "[a]ny attempt to reconstruct a legal order in a way that is not provided by a rule of this order [...] violates it. ${ }^{, 47}$

Ioannidis' argument is predicated on his contention that SC Res 1244 has a 'dual legal nature' functioning both as international law and as 'the basis

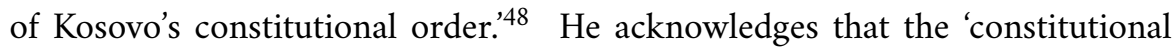
nature' of the interim legal order 'is only implied by the Court's argument, ${ }^{4}$ which acknowledged that the purpose of SC Res 1244 'is to regulate, during the interim phase [...] matters which would ordinarily be the subject of internal, rather than international, law. ${ }^{50}$ Ioannidis argues that SC Res 1244 and UNMIK Reg 1999/1 'are the bases of Kosovo's interim constitutional order' because they

${ }^{45}$ Kosovo Opinion, para 105.

${ }^{46}$ M Weller, 'Modesty Can Be Virtue: Judicial Economy in ICJ Kosovo Opinion?' (2011) 24 Leiden J of Int L 127, 146; 'Meeting Summary: Kosovo: The ICJ Opinion - What Next?', Chatham House, the Royal Institute of International Affairs, 9-10, <http://www.chathamhouse.org/publications/papers/view/109474> [accessed 17 November 2014].

${ }^{47}$ Ioannidis, 'Kosovo's Declaration of Independence and the Creation of a New Legal Order: Can a Revolution Against International Law Be Legal?' (2011) European University Institution Working Paper, LAW 2011/07, 2.

${ }^{48}$ Ibid, 1.

${ }^{49}$ Ibid, 2.

${ }^{50}$ Kosovo Opinion, para 89. The Court goes on to refer to 'the specific legal order, created pursuant to resolution 1244 (1999)' and 'the body of law adopted for the administration of Kosovo' (para 89). 
function 'as containing the ultimate norms determining the law-making organs and procedures within that territory. ${ }^{51}$ Section 1 of UNMIK Reg 1999/1 provides that '[a]ll legislative and executive authority with respect to Kosovo, including the administration of the judiciary, is vested in UNMIK'. Moreover, the Special Representative of the Secretary-General had extensive powers including the veto of legislation passed by the Provisional Institutions of Self-Government.

The specific legal order created by SC Res 1244 and UNMIK Reg 1999/1, therefore, "had the effect of superseding the legal order in force at the time in the territory of Kosovo' 52 reducing 'the FRY's sovereignty over Kosovo to a nominal title or nudum ius. ${ }^{53}$ Ioannidis argues, citing Hans Kelsen, that 'a constitution is effective if the norms produced in conformity with it are "by and large" effective" and that 'the actual ineffectiveness of FRY's laws in the territory of Kosovo mean[t] that this territory was not any more constituted by the FRY's legal order. ${ }^{54}$ Any FRY laws which remained in force 'did so because the new highest legislative authority decided upon their remaining in force. ${ }^{55}$

However, Alexandros Yannis, in his discussion of East Timor, argues that:

[...] suspension of sovereignty does not imply that the UN has assumed the sovereignty of East Timor. Suspension of sovereignty signifies rather that sovereignty is not an applicable concept any more and what matters is what are the rights and obligations of the UN transitional authority regarding the administration of the territory. 56

The same applies, I would argue, mutatis mutandis to the legal order established by SC Res 1244 and UNMIK Reg 1999/1. Moreover, 'in neither [...] Kosovo or East Timor can it seriously be argued that the transfer of authority essentially constitutes delegation of sovereign rights', and references to the agreement of the FRY are 'rather feeble attempts to produce a fig-leaf of local consent. ${ }^{\text {'57 }}$ Thus, whilst Ioannidis' analysis is correct insofar as effectiveness is concerned, he fails to acknowledge that the legitimacy of this legal order (and not, pace Vidmar, that

\footnotetext{
${ }^{51}$ Ioannidis, above n 47, 5 .

${ }^{52}$ Kosovo Opinion, 97.

${ }^{53}$ Ioannidis, above n 47, 7.

${ }^{54}$ Ibid (emphasis added in the former case; emphasis original in the latter).

${ }^{55} \mathrm{Ibid}, 7-8$.

${ }^{56}$ A Yannis, 'The Concept of Suspended Sovereignty in International Law and Its Implications in Politics' (2002) 13 EJIL 1037, 1048.

${ }^{57}$ Ibid, 1049.
} 
of the legal order constituted by the declaration of independence) is 'questionable from the perspective of the will of the people. ${ }^{58}$ Presumably it was cognisance of this which led the ICJ to imply rather than define the status of the transitional legal regime. Yannis argues that 'when there is a final settlement, sovereignty will revive and rest again with the local peoples in whatever form is envisaged for the final status of these territories. ${ }^{59}$ This understanding of suspended sovereignty, in conjunction with the ICJ's finding that the 'final settlement' of Kosovo's status was not determined by SC Res 1244 , means that it is arguable that there was no breach of the transitional legal order by the authors of the declaration because, as the Court held, they operated 'on a different level'. ${ }^{\prime 0}$

The Court's reasoning on this point is, however, problematic. In concluding its findings, the Court held that:

\begin{abstract}
[...] The declaration of independence of 17 February 2008 was not issued by the Provisional Institutions of Self-Government, nor was it an act intended to take effect, or actually taking effect, within the legal order in which those Provisional Institutions operated. It follows that the authors of the declaration of independence were not bound by the framework of powers and responsibilities established to govern the conduct of the Provisional Institutions of Self-Government $[\ldots]^{61}$
\end{abstract}

This suggests that because the authors did not intend for the declaration to take effect within the existing legal order that it follows from this that they were not bound by that legal order. However, as Judge Bennouna, dissenting, argued, 'if such reasoning is followed to its end, it would be enough to become an outlaw, as it were, in order to escape having to comply with the law. ${ }^{62}$ Or, as Kohen and Del Mar put it, an agent:

[...] that wishes to act in a way that would either fall outside its material competence or violate applicable procedural rules may claim simply not to be acting in the capacity of the organization in

\footnotetext{
${ }^{58}$ Vidmar, above n 4, 362.

${ }^{59}$ Yannis, above n 56, 1050.

${ }^{60}$ Kosovo Opinion, para 114.

${ }^{61}$ Ibid, para 121.

${ }^{62}$ Ibid, dissenting judgment of Judge Bennouna, para 46.
} 
question and call itself by a different name, in order to argue that its actions should not to be considered ultra vires. ${ }^{63}$

As Kohen and Del Mar themselves note, it is immaterial whether or not the authors were the PISG, as all the actors taking part in the political process in Kosovo were, and remain, bound by UNSCR $1244{ }^{364}$ It is immaterial not because the authors were bound regardless of their identity, but because, as Weller argues, ' $[w]$ hether or not the freely elected representatives of the people of Kosovo acted through the medium of the Assembly, their action could no longer be evaluated according to the constitutional framework. ${ }^{65}$ A declaration of independence necessarily breaches the existing legal order and cannot, therefore, be evaluated in terms derived from norms of that order.

Here the paradox of constituent power becomes clear once again. As Ioannidis argues, the only perspective available to the ICJ, from which the actions of the authors of the declaration can be evaluated, is the constitutional framework because:

[...] Even if the new regime did succeed in establishing itself in Kosovo, it did not replace or substitute the legal order on which Resolution 1244 based its validity, namely international law.

From this perspective, the ICJ is not in a position similar to that of domestic courts ultimately accepting the legality of new regimes after successful revolutions. These courts became part of a new legal order, which, after having established itself, offered the only source from which courts could derive their authority [...] To the extent that the ICJ traces its authority to the same order with Resolution 1244 , it could not accept the Declaration as the source of authority contesting the old, international law-based regime $[. . .]^{66}$

\footnotetext{
${ }^{63}$ Kohen \& Del Mar, above n $15,121$.

${ }^{64}$ Kohen \& Del Mar, above n 15, 115. Ioannidis, above n 47, 13, citing Kohen \& Del Mar: '[t]he Constitutional Framework, however, sets the procedural and substantive conditions for the creation of all norms applicable in the territory of Kosovo. These norms are binding on all natural and juridical persons within the Kosovo jurisdiction.'

${ }^{65}$ Weller, above $\mathrm{n} 46,144$.

${ }^{66}$ Ioannidis, above n 47, 14. Ionnidis also says (at 14): "[i]f the Court continues to understand itself as an organ of the same legal order that produced Kosovo's international law-based regime, it could only adopt the constitutional view of that regime.'
} 
From the perspective of the 'old regime' a declaration of independence, unless made pursuant to a norm contained within the old regime, is necessarily illegal. ${ }^{67}$ The Court was correct, therefore, to say that the declaration of independence was not 'capable' of taking effect within the existing legal order. However, if the old legal order and the new legal order did not operate on 'different levels' the ICJ was incorrect to find that there had been no violation of law. ${ }^{68}$ '[T] he problem is not,' argues Lindahl, 'that the act of the revolutionaries cannot be interpreted within the legal order they attempt to overthrow; it is that this material fact can only be interpreted as treason, not as the exercise of constituent power. ${ }^{69}$

This is the paradox of constituent power: law 'can only make sense of collective agency in terms of constituted power, power exercised in conformity with law' yet constituent power, insofar as it purports to create a new legal order, cannot act in conformity with the existing legal order. Constituent power can only, therefore, be understood as 'legal power' if it is 'retroactively interpreted as an empowered act. ${ }^{70}$ It is this issue of retroactivity which forms the crux of the Canadian Supreme Court's opinion on the legality of secession by Quebec.

\section{The will of the people and the rule of law}

Democracy is one, partial solution to the paradox of constituent power. Democracy recognises that the claim to act as constituted power 'must always be legitimated' and the 'division of powers [...] is a way of acknowledging that a people is never directly present to itself as a unity: whoever claims to speak on its behalf may only do so if the claim can be questioned by another power.' In this way, 'the rule of law gives institutional form to the ontology of collective selfhood underpinning democratic politics. ${ }^{71}$

\footnotetext{
${ }^{67}$ Ionnidis, above $\mathrm{n} 47,12$.

${ }^{68}$ I think Ionnidis may be conflating the dual status of the legal orders established by SC Res 1244, 10 June 1999 and UNMIK Reg 1999/1, 25 Jul 1999. The declaration of independence operates on the same level as the legal regime created by these instruments as they functioned domestically, that is as the temporary constitutional order of Kosovo. If that is the case the declaration of independence would breach 'domestic' law not international law. International law is not concerned with breaches of domestic law as both the ICJ and Vidmar recognize. If this is the case this may have ramifications for Ioannidis's argument regarding the ICJ's 'perspective' on the declaration.

${ }^{69}$ Lindahl, above n 21, 24 (emphasis added).

${ }^{70}$ Ibid, 11 (emphasis original).

${ }^{71}$ Ibid, 22.
} 
In the Quebec Secession Case, the Supreme Court of Canada acknowledged that "[i]t is, of course, true that democracy expresses the sovereign will of the people ${ }^{72}$ but also recognised that 'democracy in any real sense of the word cannot exist without the rule of law. ${ }^{73}$ 'It is the law,' the Court held, 'that creates the framework within which the "sovereign will" is to be ascertained and implemented. ${ }^{74}$ In contrast to Vidmar and Kohen and Del Mar, however, the Court avoided hypostatizing the legal order as 'self-grounding, self-serving and self-sustaining. ${ }^{75}$ It acknowledged that 'a system of government cannot survive through adherence to law alone. A political system must also possess legitimacy [...] [and] that requires an interaction between the rule of law and the democratic principle. $^{, 76}$

Moreover, in contradistinction to the Kosovo declaration of independence, the Canadian Court understood any prospective secession by Quebec to be an act taking place within the existing legal order: " $t$ ] he secession of a province from Canada must be considered, in legal terms, to require an amendment to the Constitution" ${ }^{\text {,7 }}$ and "[a]ny attempt to effect the secession of a province from Canada must be undertaken pursuant to the Constitution of Canada, or else violate the Canadian legal order., ${ }^{78}$ 'The Constitution,' the Court held:

[...]is the expression of the sovereignty of the people of Canada. It lies within the power of the people of Canada, acting through their various governments duly elected and recognized under the Constitution, to effect whatever constitutional arrangements are desired [... $]^{79}$

Thus, not only was the Court only able to interpret secession as an act taking place within the existing legal order, it was only able to understand its quality as an act of constituent power as being first of all an act of constituted power; an act of the 'various governments duly elected and recognised under the Constitution. ${ }^{80}$

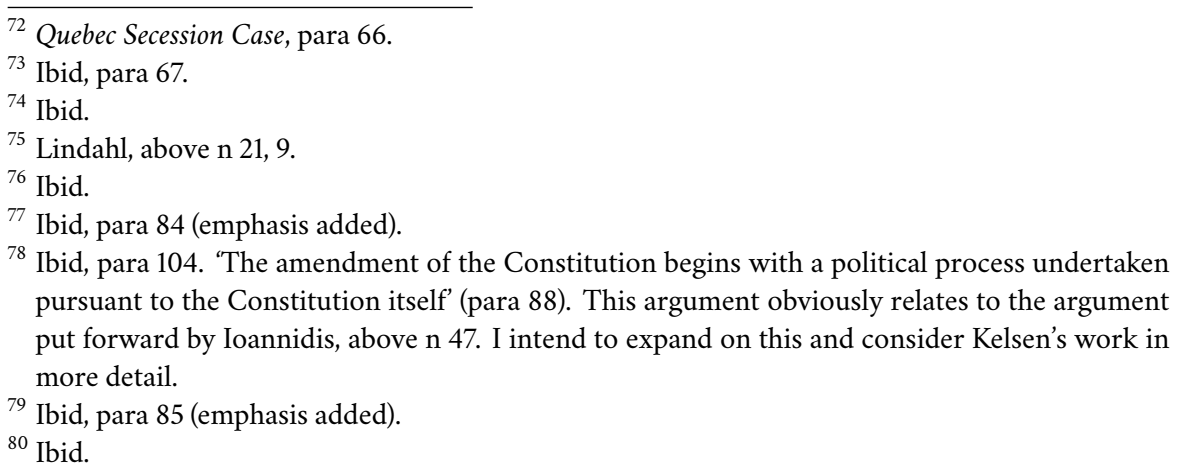


The Court acknowledged, however, that "[a]lthough under the Constitution there is no right to pursue secession unilaterally [...] this does not rule out the possibility of an unconstitutional declaration of secession leading to a de facto secession. ${ }^{\prime 1}$ The Court held, correctly, that the 'alleged principle of effectivity [...] does not provide an ex ante explanation or justification for an act.' ${ }^{82}$ Moreover, like Kohen and Del Mar, Judge Bennouna, and arguably the ICJ, the Court recognised that to accept the principle of effectivity would amount to 'accepting that [...] Quebec may act without regard to the law,' that it may act outside of the Canadian legal order, 'simply because it asserts the power to do so. ${ }^{, 83}$ 'Such a notion', the Court held, 'is contrary to the rule of law', ${ }^{84}$ or, in Lindahl's terms, 'can only be interpreted as treason, not as the exercise of constituent power.' The Court held that de facto secession does not provide justification ex ante, but also that recognition by other states 'does not relate back to the date of secession to serve retroactively as a source of "legal" right to secede. ${ }^{\text {, } 5}$

From the perspective of the old regime (the only perspective which the Supreme Court of Canada could possibly take) this is undoubtedly true. From the perspective of the new regime, however, this 'fabulous retroactivity' is precisely the way in which the legality and legitimacy of the constituent act is established. As Derrida says, 'the coup of force makes right, founds right or the law, gives right. $^{\text {'86 }}$

\section{Conclusion: the necessity of the last instance}

As both the Supreme Court of Canada and Lindahl recognise, there is a limit to democracy and the rule of law's ability to 'institutionalise' the paradox of constituent power. The ability of the collective self, the 'We' which is both

\footnotetext{
${ }^{81}$ Ibid, para 106.

${ }^{82}$ Ibid, para 107.

${ }^{83}$ Ibid. The Court recognises that 'ex hypothesi [a] successful revolution took place outside the constitutional framework of the predecessor state, otherwise it would not be characterized as a "revolution"' (para 144).

${ }^{84} \mathrm{Ibid}$, para 108.

${ }^{85}$ Quebec Secession Case, para 142. Two paragraphs later, the Court re-iterates: '[i]t may be that a unilateral secession by Quebec would eventually be accorded legal status by Canada and other states, and thus give rise to legal consequences; but this does not support the more radical contention that subsequent recognition of a state of affairs brought about by a unilateral declaration of independence could be taken to mean that secession was achieved under colour of a legal right.'

${ }^{86}$ Derrida, above n 27, 10.
} 
constituent and constituted power, to accommodate contests of representational claims is finite: 'there is a form of constituent power [...] that proceeds from a radical outside no political community succeeds in domesticating. ${ }^{, 87}$ Moreover, these decisions illustrate the limited ability of courts to adjudicate acts of constituent power. Both the ICJ and the Supreme Court of Canada trace their authority, their capacity to judge, back to the legal order which was, or would be contested, by the acts of this 'radical' constituent power and in both instances constituent power was only justiciable to the extent that it claimed to be constituted power. To the extent that exercises of constituent power cannot be accommodated by norms of an existing legal order, they must be translated into constituted power by another means. The success of any declaration is, therefore, dependent on someone other than the author(s) of the statement ${ }^{88}$. It is not enough simply to represent reality as being changed. The authors' representative capacity is, in Searle's terminology, a status function, that is a 'a function [...] where the objects and the people cannot perform the function solely in virtue of their physical structure' and the 'performance of the function requires that there be a collectively recognised status that the person or object has, and it is only in virtue of that status that the person or object can perform the function in question. ${ }^{89}$ Necessarily, this recognition can only be given after the fact and in this way the change in reality which is represented as already existing at the time of the utterance takes effect retroactively. Moreover, institutional facts (such as 'the People') require 'continued recognition or acceptance because they exist only as long as they are recognized or accepted. ${ }^{\prime 90}$ Searle says that '[o]ne mark of recognition or acceptance is continued usage of the institution and institutional facts, ${ }^{91}$ echoing Lindahl's suggestion that it is the uptake of constitutional rights by the collective which legitimates the authors' claim to representivity. The requirement of recognition is not, necessarily, limited to

\footnotetext{
${ }^{87}$ Lindahl, above n 21, 22.

${ }^{88}$ Derrida puts the this way: "[a]nother "subjectivity" is still coming to sign, in order to guarantee it, this production of signature. In short, there are only countersignatures in this process.' In the case of the American Declaration of Independence the people 'sign in the name of the laws of nature and in the name of God ... He comes, in effect, to guarantee the rectitude of popular intentions, the unity and goodness of the people. He founds natural laws and thus the whole game which tends to present performative utterances as constative utterances.' For a Declaration of Independence to have 'meaning and effect there must be this last instance.' Derrida, above n 27, 11,12 .

${ }^{89}$ Searle, above n $19,8$.

${ }^{90}$ Ibid, 103.

${ }^{91}$ Searle, above n 19, 103.
} 
the members of one community to which the authors belong. For example, the authors of the declaration require not only the recognition of the members of the community on whose behalf they claim to act but also, arguably, the recognition of the international community of states. ${ }^{92}$ Crucially, however, this recognition can only ever be granted ex post facto and the representative status of the authors achieved only retroactively. In order to understand the ontology of 'the People' (and institutional facts generally) one must remember that '[y] ou make something the case by representing it as being the case. ${ }^{, 93}$ This insight provides a partial solution to the paradox of constituent power. Constituent power can only be rendered intelligible when it is understood to act as constituted power. This is not because constituent power is necessarily unique, but rather because this is the logical structure which underpins all institutional reality.

\footnotetext{
${ }^{92}$ I believe that Searle's account of the ontology of institutional facts has ramifications for the doctrine of recognition in international law, an idea which I will develop in a future article.

${ }^{93}$ Searle, above n 19, 120.
} 